\title{
Clay Minerals in Hydrothermal Systems
}

\author{
Paolo Fulignati D \\ Dipartimento di Scienze della Terra, University of Pisa, Via S. Maria 53, 56126 Pisa, Italy; paolo.fulignati@unipi.it \\ Received: 24 August 2020; Accepted: 14 October 2020; Published: 16 October 2020

\begin{abstract}
The study of active and fossil hydrothermal systems shows clay minerals to be a fundamental tool for the identification and characterization of hydrothermal alteration facies. The occurrence and composition of hydrothermal alteration facies could provide useful information on the physicochemical conditions of the hydrothermal activity affecting a rock volume. In particular, clay minerals (i.e., smectite group, chlorite, illite, kaoline group, pyrophyllite, biotite) are pivotal for extrapolating important parameters that strongly affect the development of water/rock interaction processes such as the temperature and $\mathrm{pH}$ of the hydrothermal environment. This work aims to give a general reference scheme concerning the occurrence of clay minerals in hydrothermal alteration paragenesis, their significance, and the information that can be deduced by their presence and chemical composition, with some examples from active and fossil hydrothermal systems around the world. The main mineralogical geothermometers based on chlorite and illite composition are presented, together with the use of hydrogen and oxygen isotope investigation of clay minerals in hydrothermal systems. These techniques provide a useful tool for the reconstruction of the origin and evolution of fluids involved in hydrothermal alteration. Finally, a list of oxygen and hydrogen fractionation factor equations between the main clay minerals and water is also provided.
\end{abstract}

Keywords: clay minerals; hydrothermal alteration; hydrothermal mineralogical paragenesis; geothermometers

\section{Introduction}

A volume of rock, when affected by hydrothermal fluid circulation, typically undergoes a variety of alteration processes. This is due to the instability of the primary mineralogical assemblages under the new physicochemical conditions, which leads to the formation of new mineral phases [1]. This phenomenon is commonly known as hydrothermal alteration. In the study of active and fossil hydrothermal systems, alteration minerals provide very useful information about the physicochemical conditions of the hydrothermal activity that affect (or have affected) a volume of rock [2]. In particular, it has been shown that clay minerals, which in hydrothermal systems are typical and widespread alteration products, can be considered as circulation zone markers, based on their reactivity to changes in the physicochemical conditions of the hydrothermal fluids [3-17]. The properties of clay minerals are primarily affected by temperature in addition to several other factors, such as the rock and fluid chemistries, time, and the fluid/rock ratio. Numerous studies have considered both the sequential distribution from smectites to the non-expandable di- or tri-octahedral phyllosilicates and the chemical variations of the non-expandable clay phases (chlorite and/or illite) as a function of the past and present thermal conditions $[5,10,18,19]$. As the compositional variation of clay minerals (in particular chlorite and illite) is particularly sensitive to the formation conditions, thus, in the last 35 years, several empirically or thermodynamically based geothermometers have been proposed, that were particularly calibrated for low-temperature context $\left(\mathrm{T}<350^{\circ} \mathrm{C}\right)$ typical of hydrothermal alteration [20-30].

The present review aims to introduce the reader to the study of clay minerals in hydrothermal systems, giving a general reference scheme regarding the occurrence of clay minerals in hydrothermal 
alteration paragenesis, their significance, and the main information that can be deduced by their presence and chemical composition. These data are precious in geothermal exploration and in the study of hydrothermal ore deposits, inasmuch as they help define the conceptual "working model" of active and fossil hydrothermal systems. As a first step toward the use of stable isotope composition of clay minerals for the study of hydrothermal systems, a list of oxygen and hydrogen fractionation factor equations between the main clay minerals and water is provided at the end of the article.

\section{Hydrothermal Alteration Paragenesis}

The hydrothermal alteration process comprehends mineralogical, chemical, and textural changes, resulting from the interaction between hot and aggressive fluids and the rocks through which they pass. Hydrothermal fluids chemically attack the primary mineral phases constituting the host rock, which tend to re-equilibrate by generating new mineralogical assemblages (hydrothermal alteration mineralogical paragenesis or hydrothermal alteration facies) in equilibrium with the new conditions. As a result, the new phases mainly consist of hydrous minerals, with clay minerals being the most important category. For a new mineral or mineralogical assemblage to be stable within a hydrothermal alteration environment, it must satisfy the thermal stability requirements and be compatible with the composition of the coexisting solution [11]. Representative examples of important hydrothermal mineral equilibria can be expressed in isothermal activity diagrams [11,31-33], as shown in Figure 1. These data are an approximation of the real development of secondary mineralogical assemblages; however, they provide a useful understanding of the basic concepts of alteration mineralogy and are particularly helpful in visualizing wall-rock alteration processes. On this basis, the correct identification and characterization of hydrothermal alteration paragenesis allows constraining the chemical-physical characteristics (i.e., temperature and $\mathrm{pH}$ conditions) of the environment in which the hydrothermal alteration developed. As a consequence, the investigation of hydrothermal mineralogical assemblages is pivotal for the reconstruction of a conceptual model of both active (geothermal systems) and fossil (hydrothermal ore deposits) systems. The main types of hydrothermal alteration facies and their indicative $\mathrm{T}$ and $\mathrm{pH}$ conditions of formation are listed in Table 1 . We can observe how clay minerals are among the key phases that help to characterize the alteration facies. The importance of clay minerals in the characterization of alteration facies, and in particular in the identification of the hydrothermal alteration zoneography of active geothermal systems, is well evidenced in the examples shown in Figure 2.

Table 1. Main types of hydrothermal alteration facies and their indicative $\mathrm{T}$ and $\mathrm{pH}$ conditions of formation.

\begin{tabular}{ccc}
\hline Hydrothermal Alteration Facies & $\mathbf{p H}$ & Temperature \\
\hline Argillic & $5.5-7$ & $<160{ }^{\circ} \mathrm{C}$ \\
\hline Intermediate argillic & $4-5.5$ & $<160{ }^{\circ} \mathrm{C}$ \\
\hline Advanced argillic & $2-4$ & $<160-300{ }^{\circ} \mathrm{C}$ \\
\hline Phyllic & $5.5-7$ & $160-230{ }^{\circ} \mathrm{C}$ \\
\hline Propylitic & $5.5-7$ & $230-350{ }^{\circ} \mathrm{C}$ \\
\hline Alkali metasomatism & $5.5-7$ & $>350{ }^{\circ} \mathrm{C}$ \\
\hline
\end{tabular}



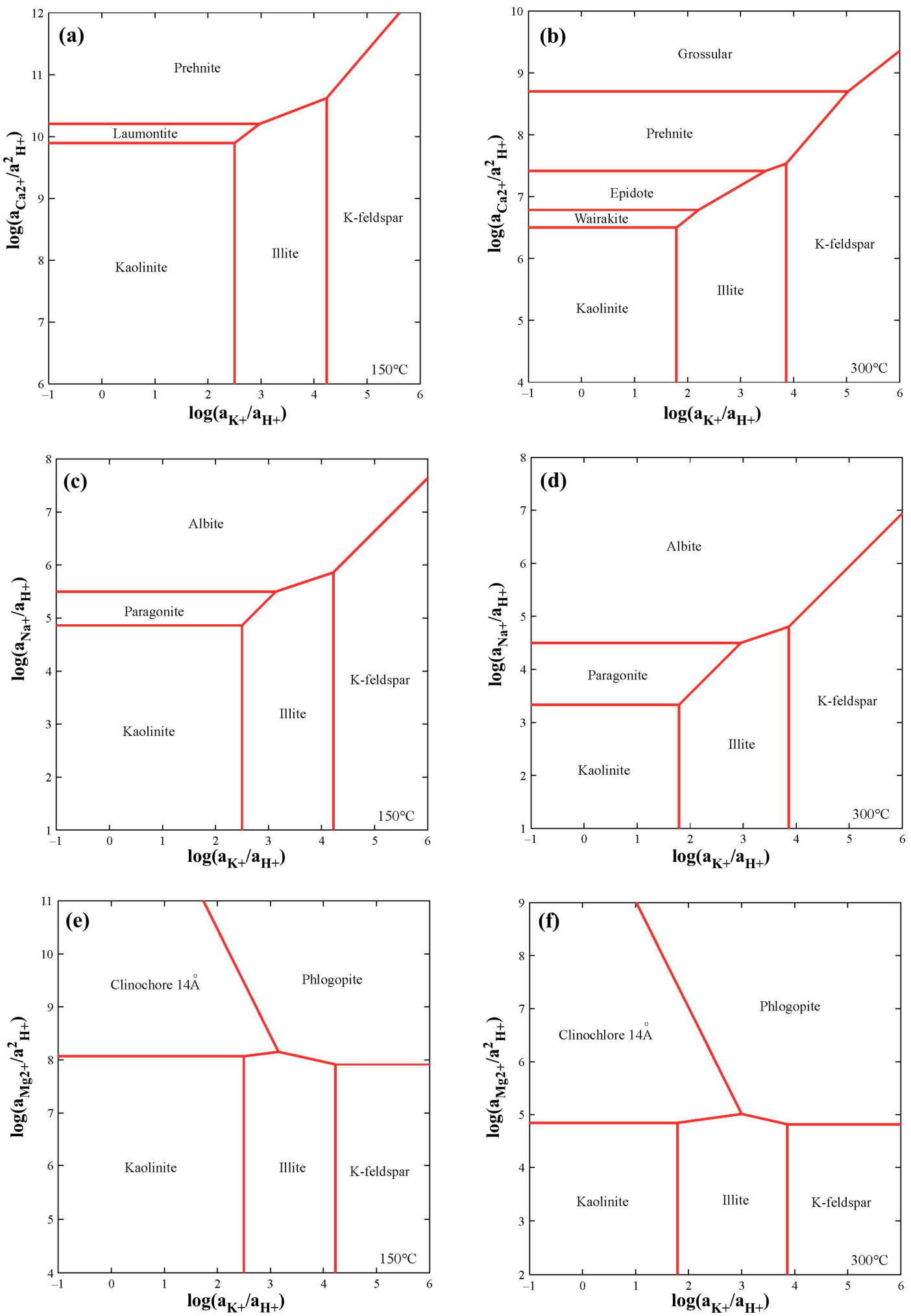

Figure 1. Stability diagrams as a function of cation activity ratios at constant temperature: (a) the system $\mathrm{K}_{2} \mathrm{O}-\mathrm{CaO}-\mathrm{Al}_{2} \mathrm{O}_{3}-\mathrm{SiO}_{2}-\mathrm{H}_{2} \mathrm{O}$ at $150{ }^{\circ} \mathrm{C}$, (b) the same system at $300{ }^{\circ} \mathrm{C}$, (c) the system $\mathrm{K}_{2} \mathrm{O}-\mathrm{Na}_{2} \mathrm{O}-\mathrm{CaO}-\mathrm{Al}_{2} \mathrm{O}_{3}-\mathrm{SiO}_{2}-\mathrm{H}_{2} \mathrm{O}$ at $150{ }^{\circ} \mathrm{C}$, (d) the same system at $300{ }^{\circ} \mathrm{C}$, (e) the system $\mathrm{K}_{2} \mathrm{O}-\mathrm{MgO}-\mathrm{Al}_{2} \mathrm{O}_{3}-\mathrm{SiO}_{2}-\mathrm{H}_{2} \mathrm{O}$ at $150{ }^{\circ} \mathrm{C}$, and (f) the same system at $300{ }^{\circ} \mathrm{C}$. The diagrams were generated with the Act2 application of the Geochemist 's Workbench. For thermodynamic data of minerals, see Bethke [34] and references therein. 
(a)

\begin{tabular}{|c|c|c|c|}
\hline $\begin{array}{c}\text { CLAYS + } \\
\text { ZEOLITE } \\
\text { ZONE }\end{array}$ & $\begin{array}{l}\text { CALCITE + } \\
\text { CHLORITE + } \\
\text { ILLITE ZONE }\end{array}$ & $\begin{array}{c}\text { CHLORITE + } \\
\text { QUARTZ + } \\
\text { EPIDOTE ZONE }\end{array}$ & $\begin{array}{l}\text { MINERALOGY } \\
\text { ZONE }\end{array}$ \\
\hline " & 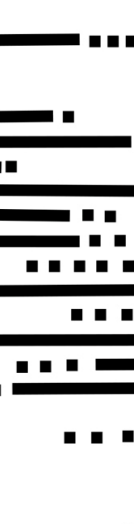 & 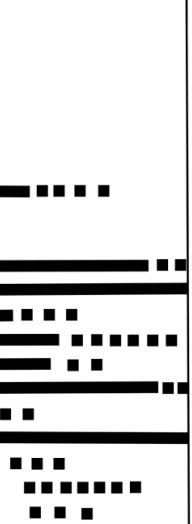 & $\begin{array}{l}\text { SALTS, NAT. SULPHUR } \\
\text { SMECTITE } \\
\text { AMORPHOUS SILICA } \\
\text { PTILOLITE, LAUMONTITE } \\
\text { DOLOMITE } \\
\text { KAOLINITE } \\
\text { ALBITE } \\
\text { CALCITE } \\
\text { TITANITE } \\
\text { PYRITE } \\
\text { HEMATITE, ANATASE } \\
\text { QUARTZ } \\
\text { ANHYDRITE } \\
\text { ILLITE } \\
\text { WAIRAKITE } \\
\text { CHLORITE } \\
\text { GEDRITE } \\
\text { EPIDOTE } \\
\text { DIOPSIDE } \\
\text { PHRENITE } \\
\text { K-FELDSPAR }\end{array}$ \\
\hline
\end{tabular}

(b)

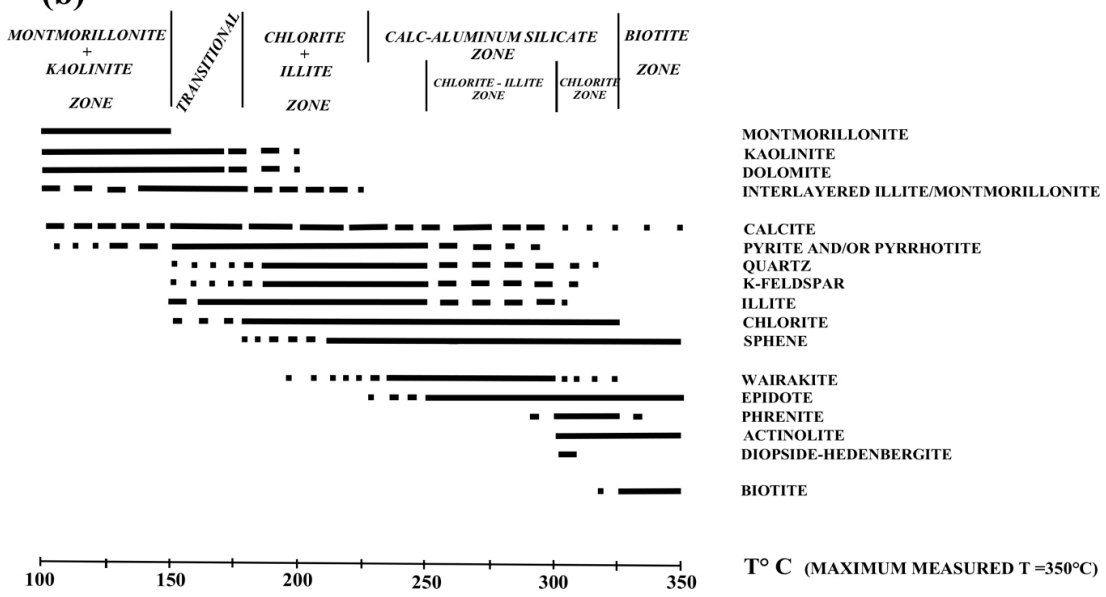

Figure 2. Mineral zoneography as a function of temperature reported for: (a) Los Azufres (redrawn from Cathelineau et al. [35]) and (b) Cerro Prieto (redrawn from Elders et al. [36]) geothermal fields.

\section{Main Clay Mineral Groups and Their Significance in Hydrothermal Alteration Paragenesis}

\subsection{Smectite Group}

The smectite group comprehends dioctahedral and trioctahedral subgroups. The most common dioctahedral smectites are: montmorillonite $\left[\left(\mathrm{Na}, \mathrm{Ca}_{0.5}\right)_{0.66}\left(\mathrm{Al}_{3.34} \mathrm{Mg}_{0.66}\right) \mathrm{Si}_{8} \mathrm{O}_{20}(\mathrm{OH})_{4}\right]$, beidellite $\left[\left(\mathrm{Na}, \mathrm{Ca}_{0.5}\right)_{0.66} \mathrm{Al}_{4}\left(\mathrm{Si}_{7.34} \mathrm{Al}_{0.66}\right) \mathrm{O}_{20}(\mathrm{OH})_{4}\right]$, and nontronite $\left[\left(\mathrm{Na}, \mathrm{Ca}_{0.5}\right)_{0.66} \mathrm{Fe}^{3+}{ }_{4}\left(\mathrm{Si}_{7.34} \mathrm{Al}_{0.66}\right) \mathrm{O}_{20}(\mathrm{OH})_{4}\right]$. The trioctahedral smectites are represented here by the type mineral saponite $\left[\left(\mathrm{Na}, \mathrm{Ca}_{0.5}\right)_{0.66}\left(\mathrm{Mg}, \mathrm{Fe}^{2+}\right)_{6}\left(\mathrm{Si}_{7.34} \mathrm{Al}_{0.66}\right) \mathrm{O}_{20}(\mathrm{OH})_{4}\right]$. The smectites are commonly found in hydrothermal alteration paragenesis. They generally occur in the argillic alteration facies (Table 2), and are the typical product of hydrolysis reactions (see Equation (1)) at the expense of silicate phases (plagioclase, feldspar, pyroxene, olivine, volcanic glass) under relatively neutral $\mathrm{pH}$ values $(\sim 5.5-7)$ and generally at temperature below $160^{\circ} \mathrm{C}$.

$$
\begin{gathered}
\text { 1.17 } \\
\text { Albite }
\end{gathered}
$$


Table 2. Clay minerals typically present in hydrothermal environment as a function of alteration facies, associated minerals, and indicative $\mathrm{pH}$ and temperature of formation (see text, Section 3 , for discussion and references).

\begin{tabular}{|c|c|c|c|c|}
\hline Clay Minerals & Associated Minerals & $\begin{array}{c}\text { Hydrothermal } \\
\text { Alteration Facies }\end{array}$ & $\mathrm{pH}$ & Temperature \\
\hline Dioctahedral smectites & Zeolite group & Argillic & $5.5-7$ & $<160^{\circ} \mathrm{C}$ \\
\hline Trioctahedral smecitites * & Zeolite group & Argillic & $5.5-7$ & $<160^{\circ} \mathrm{C}^{* *}$ \\
\hline Sepiolite-palygorskite & $\begin{array}{l}\text { di-trioctahedral } \\
\text { smectites }\end{array}$ & Argillic & $5.5-8$ & $<160{ }^{\circ} \mathrm{C}$ \\
\hline Kaoline group & $\begin{array}{c}\begin{array}{c} \pm \text { smectites } \\
\text { alunite }\end{array} \\
\end{array}$ & Intermediate argillic & $4.5-6$ & $<200^{\circ} \mathrm{C}$ \\
\hline Pyrophyllite & alunite & High-T advanced argillic & $2-4$ & $200-300^{\circ} \mathrm{C}$ \\
\hline Mixed layers I/S & Mixed layers $\mathrm{C} / \mathrm{S} \pm$ illite & Phyllic & $5.5-7$ & $150-220^{\circ} \mathrm{C}$ \\
\hline Mixed layers $C / S$ & Mixed layers I/S \pm illite & Phyllic & $5.5-7$ & $160-250{ }^{\circ} \mathrm{C}$ \\
\hline Illite & $\begin{array}{l}\text { chlorite, adularia, albite, } \\
\text { epidote, quartz } \pm \text { biotite } \\
\pm \text { garnet } \pm \text { amphibole }\end{array}$ & Propylitic & $5.5-7$ & $220-350^{\circ} \mathrm{C}$ \\
\hline Chlorite & $\begin{array}{l}\text { chlorite, adularia, albite, } \\
\text { epidote, quartz } \pm \text { biotite } \\
\pm \text { garnet } \pm \text { amphibole }\end{array}$ & Propylitic & $5.5-7$ & $220-350{ }^{\circ} \mathrm{C}$ \\
\hline Talc & $\begin{array}{l}\text { chlorite, illite, adularia, } \\
\text { albite, epidote, quartz }\end{array}$ & Propylitic & $5.5-7$ & $250-300{ }^{\circ} \mathrm{C}$ \\
\hline Serpentine group & chlorite, talc & Propylitic & $5.5-7$ & $250-350{ }^{\circ} \mathrm{C}$ \\
\hline Mixed layers B/V & $\begin{array}{l}\text { chlorite, illite, adularia, } \\
\text { albite, epidote, quartz }\end{array}$ & Propylitic & $5.5-7$ & $250-320^{\circ} \mathrm{C}$ \\
\hline Biotite & $\begin{array}{c}\text { K-feldspar } \pm \text { garnet } \pm \\
\text { amphibole } \pm \\
\text { clinopyroxene }\end{array}$ & Alkali metasomatism & $5.5-7$ & $>320^{\circ} \mathrm{C}$ \\
\hline
\end{tabular}

Saponite and more rarely dioctahedral smectites have been sometimes found in higher temperature hydrothermal zones (propylitic facies) of active geothermal systems [12-14,37,38], such as those found at Milos (Greece), Chipilapa (El Salvador), Pantelleria (Italy), Tendaho (Ethiopia), and Berlin (El Salvador). These are considered as metastable phases, whose transformation toward illite or chlorite is kinetically controlled (temperature- and time-dependent), of a newly formed geothermal reservoir where high fracture permeability and boiling fluid are present [12,37]. The smectite transition toward illite and chlorite, through mixed layers illite/smectite (I/S) and chlorite/smectite (C/S), is typically related to an increase in crystallization temperature and is presented below.

Vermiculite $\left[(\mathrm{Mg}, \mathrm{Ca})_{0.7}\left(\mathrm{Mg}, \mathrm{Fe}^{3+} \mathrm{Al}\right)_{6}\left(\mathrm{Si}_{7.34} \mathrm{Al}_{0.66}\right) \mathrm{O}_{20}(\mathrm{OH})_{4}\right]$ could well be regarded as a trioctahedral member of the smectite group and is chemically very similar to saponite [39] but with a higher interlayer charge. It is characterized by a larger cation deficiency, caused by $\mathrm{Al}^{3+}$ (and sometimes $\mathrm{Fe}^{3+}$ ) substitution of $\mathrm{Si}^{4+}$ in tetrahedral sites, compensated by the occurrence of about 0.7 divalent cations ( $\mathrm{Ca}$ and $\mathrm{Mg}$ ) in the interlayer site. The significance of vermiculite is substantially the same as that of other smectite group minerals and is typically found in argillic hydrothermal alteration facies.

\subsection{Kaolinite Group}

The kaolinite $\left[\mathrm{Al}_{4} \mathrm{Si}_{4} \mathrm{O}_{10}(\mathrm{OH})_{8}\right]$ group minerals (kaolinite, halloysite, dickite, and nacrite) are the key minerals of the intermediate argillic alteration facies (Table 2) and may also locally occur in advanced argillic facies. Their presence in hydrothermal alteration paragenesis indicates relatively low fluid temperature $\left(\mathrm{T}<150-200^{\circ} \mathrm{C}\right)$. The kaolinite group minerals represent a more advanced product 
of hydrolysis reactions (see Equation (2)) at the expense of silicate phases with respect to smectites, due to the higher $\mathrm{H}^{+}$activity in hydrothermal fluids.

$$
\begin{aligned}
& 3 \mathrm{Na}_{0.33} \mathrm{Al}_{2.33} \mathrm{Si}_{3.67} \mathrm{O}_{10}(\mathrm{OH})_{2}+\mathrm{H}^{+}+3.5 \mathrm{H}_{2} \mathrm{O}=3.5 \mathrm{Al}_{2} \mathrm{Si}_{2} \mathrm{O}_{5}(\mathrm{OH})_{4}+4 \mathrm{SiO}_{2}+\mathrm{Na}^{+} \\
& \text {Na-montmorillonite } \\
& \text { kaolinite }
\end{aligned}
$$

Indeed, they can be used as a geoacidometer being stable at $\mathrm{pH}$ values ranging from about 4.5 to 6 [40,41]. Studies on alunite-supergroup (aluminum-phosphates-sulphates, APS) minerals bearing kaolinite deposits of hydrothermal origin, in the circum-Pacific Rim fold belts (El Salvador, Peru, Bolivia, Chile, and Indonesia), showed that the interrelationship of APS minerals with predominantly kaolinite-group minerals can be useful for the characterization of the physicochemical (particularly temperature) conditions of formation [42-45]. This is because APS minerals are sometimes more sensitive to changes in the physicochemical conditions during hydrothermal alteration processes than phyllosilicates. These works suggest that the mineralogical assemblage of APS-bearing kaolinite deposits as well as the mineral zonation of APS minerals can provide constraints on the temperature regime during hydrothermal alteration [45].

\subsection{Pyrophyllite Group}

Pyrophyllite $\left[\mathrm{Al}_{4} \mathrm{Si}_{8} \mathrm{O}_{20}(\mathrm{OH})_{4}\right]$ can be considered (to some extent) the high-temperature equivalent of kaolinite. Indeed, it develops from acidic hydrothermal fluids ( $\mathrm{pH}$ as low as 2 [46]) at temperatures from 200 to $250{ }^{\circ} \mathrm{C}$ up to about $300{ }^{\circ} \mathrm{C}[7,47,48]$, and is typically found in hydrothermal alteration paragenesis (Table 2) of high-sulfidation epithermal ore deposits [44], where it may represent the root zone of advanced argillic lithocaps [46].

\subsection{Illite}

The term illite refers here to the dioctahedral fine-grained mica (ideal formula $\left[\mathrm{K}_{1-\mathrm{x}} \mathrm{Al}_{2}\left(\mathrm{Si}_{3+\mathrm{x}} \mathrm{Al}_{1-\mathrm{x}}\right) \mathrm{O}_{10}(\mathrm{OH})_{2}\right]$, with $\mathrm{x} \sim 0.15-0.40$ [49]) that typically occurs in phyllic and particularly in propylitic alteration facies of hydrothermal systems (Table 2). In older literature, the term sericite was also used, but more recently, the term illite is being preferably used [11]. In a hydrothermal environment, illite generally forms at temperatures above $200-220^{\circ} \mathrm{C}$ up to about $350^{\circ} \mathrm{C}$ as an alteration of K-feldspar and plagioclase. Ideally, illite often undergoes regular compositional substitutions. In particular, $\mathrm{Fe}$ and $\mathrm{Mg}$ (phengitic component) can substitute $\mathrm{Al}$ in octahedral position according to the substitution: $\left(\mathrm{Fe}^{2+}, \mathrm{Mg}\right)^{\mathrm{VI}}+\left(\mathrm{Si}^{4+}\right)^{\mathrm{IV}}=\left(\mathrm{Al}^{3+}\right)^{\mathrm{VI}}+\left(\mathrm{Al}^{3+}\right)^{\mathrm{IV}}[5,23]$. The illite composition shows systematic variations with increasing crystallization temperature, particularly an increase in K content and total interlayer occupancy (high-temperature illite approximates the typical muscovite composition $\left.\left[\mathrm{K}_{1} \mathrm{Al}_{2}\left(\mathrm{Si}_{3} \mathrm{Al}_{1}\right) \mathrm{O}_{10}(\mathrm{OH})_{2}\right]\right)$. These chemical variations were used (see below) for calibrating useful geothermometers for estimating alteration temperature conditions $[23,24,28]$.

\subsection{Chlorite}

Chlorite group minerals have the general formula $\mathrm{A}_{12} \mathrm{Z}_{8} \mathrm{O}_{20}(\mathrm{OH})_{16}$ with the A site occupied by $\mathrm{Fe}, \mathrm{Mg}, \mathrm{Al}, \mathrm{Mn}$, and less common $\mathrm{Cr}, \mathrm{Ni}, \mathrm{Li}$, and the $\mathrm{Z}$ site by $\mathrm{Si}$ and $\mathrm{Al}$ (a minor amount of $\mathrm{Fe}^{3+}$ may sometimes also occur). Chlorite is a mineral commonly found in propylitic alteration facies (Table 2). It suggests temperatures generally above $220^{\circ} \mathrm{C}$, and it mainly occurs in veins and as an alteration of mafic minerals (pyroxene and olivine). Chlorite, like illite, shows systematic variations in its chemical composition, which are related to the formation temperature. This has allowed the development of several useful geothermometers [20-22,24-27,29,30] since the 1980s (see below), which have been widely adopted in many studies on hydrothermal alteration in active and fossil hydrothermal systems [13,14,19-21,38,50-59]. 


\subsection{Biotite}

Biotite is a trioctahedral mica (the ideal formula is $\left.\left[\mathrm{K}_{2}\left(\mathrm{Mg}, \mathrm{Fe}_{6}\right)_{6}\left(\mathrm{Si}_{6} \mathrm{Al}_{2}\right) \mathrm{O}_{20}(\mathrm{OH})_{4}\right]\right)$ that is commonly found in the high-temperature alteration facies of hydrothermal alteration. It generally occurs as fine-grained crystals and is characterized by a low Ti content, which tends to increase with increasing the crystallization temperature as well as the interlayer occupancy $[5,60]$. In a hydrothermal environment, biotite is a characteristic mineral of alkali metasomatism facies (e.g., potassic facies in porphyry copper systems, Table 2). It can also be found in propylitic alteration facies, where the biotite occurrence marks an isograde around $320-330^{\circ} \mathrm{C}[5,47,55]$. As a consequence, the appearance of biotite (together with other high-T minerals such as garnet, amphibole, clinopyroxene) in the propylitic facies of the reservoir zone of a geothermal system suggests that the circulated fluids reached high temperatures, above $\sim 350{ }^{\circ} \mathrm{C}$.

\subsection{Talc}

Talc (the ideal formula is $\left[\mathrm{Mg}_{3} \mathrm{Si}_{4} \mathrm{O}_{10}(\mathrm{OH})_{2}\right]$ ) occurs mainly in propylitic alteration facies (Table 2) as a replacement of olivine and as vein-fillings of mafic and ultramafic rocks. It is a typical hydrothermal mineral present in the alteration paragenesis of ultramafic-hosted hydrothermal systems at mid-ocean ridges. Talc occurrence suggests a temperature of around $250-300{ }^{\circ} \mathrm{C}[5,18,61]$.

\subsection{Serpentine Group}

Serpentine is a Mg-Fe-bearing phyllosilicate $\left(\left[\left(\mathrm{Mg}, \mathrm{Fe}_{3} \mathrm{Si}_{2} \mathrm{O}_{5}(\mathrm{OH})_{4}\right]\right)\right.$ that displays three polymorphs: antigorite, lizardite, and chrysotile. In a hydrothermal environment, the serpentine group minerals are found as an alteration of ultramafic rocks by means of seawater-dominated fluids at a temperature ranging between 250 and $350^{\circ} \mathrm{C}[41,62,63]$, and they can be locally found in propylitic alteration facies.

\subsection{Sepiolite-Palygorskite}

Sepiolite $\left[\mathrm{Mg}_{4}\left(\mathrm{Si}_{6} \mathrm{O}_{15}\right)(\mathrm{OH})_{2} \cdot 6 \mathrm{H}_{2} \mathrm{O}\right]$ and palygorskite $\left[(\mathrm{Mg}, \mathrm{Al})_{5}(\mathrm{Si}, \mathrm{Al})_{8} \mathrm{O}_{20}(\mathrm{OH})_{2} \cdot 8 \mathrm{H}_{2} \mathrm{O}\right]$, albeit not true phyllosilicates in the strict sense because of their fiber structure, are generally attributed to this class of silicates [41]. Like the serpentine group minerals, sepiolite/palygorskite are found as a hydrothermal alteration of mafic and ultramafic rocks of the oceanic crust. The formation model for sepiolite/palygorskite includes the hydrothermal transformation of magnesite, dolomite, and/or serpentine, and their occurrence reflects a temperature of formation lower than that of talc (Reference [64] and references therein) and can be locally found in argillic alteration facies (indicative temperature below $160^{\circ} \mathrm{C}$ ).

\subsection{Mixed Layers}

Mixed-layer clay minerals are intermediate products of reactions involving pure end-member clays. Most often, mixed layering involves essentially two components, but more complicated interstratifications have also been documented [65]. Among the large variety of mixed layer clay minerals that have been identified in the natural environment, three types (mixed layers chlorite/smectite, illite/smectite, and biotite/vermiculite) that are the most commonly found in hydrothermal alteration paragenesis will be discussed in detail.

\subsubsection{Mixed-Layer Chlorite/Smectite (C/S)}

The smectite to chlorite transition, through mixed-layer chlorite-smectite, is strictly related to the increase in formation temperature. The transition is characterized by an increase in the percentage of chlorite layers in mixed-layer $\mathrm{C} / \mathrm{S}$ with temperature and spans a temperature interval ranging approximately between 160 and $180^{\circ} \mathrm{C}$ and $240-250^{\circ} \mathrm{C}[4,10,13,15,17,65-67]$. The smectite to chlorite transition occurs by the formation of a random mixed-layer $\mathrm{C} / \mathrm{S}$ and the formation of 
regularly interstratified 1:1 C/S (corrensite), which behaves (also thermodynamically) as a stable C/S phase $[66,68,69]$. The first appearance of corrensite was reported between 150 and $200{ }^{\circ} \mathrm{C}$, and its presence was sometimes noted up to temperatures of approximately $300^{\circ} \mathrm{C}[10,18]$. In hydrothermal systems, the smectite to chlorite transition may occur either continuously, characterized by $\mathrm{C} / \mathrm{S}$ of variable percentage chlorite $[10,70,71]$, or discontinuously, characterized by discrete phases (including corrensite) $[15,66,68]$. Mixed-layer C/S typically occur in phyllic alteration facies (Table 2).

\subsubsection{Mixed-Layer Illite/Smectite (I/S)}

Similar to the smectite-chlorite transition, the smectite to illite conversion occurs through mixed-layer illite/smectite and is related to the increase in formation temperature. In a hydrothermal environment, the smectite illitization via mixed-layer I/S occurs in the temperature range $150-220^{\circ} \mathrm{C}[5,8,16,51,72-74]$, and mixed-layer I/S are characteristic of phyllic alteration facies (Table 2). According to the works of Inoue et al. [73] and Murakami et al. [74] on the smectite to illite transition in the Kakkonda geothermal system, smectite illitization probably does not occur by a layer-by-layer mechanism via $\mathrm{K}$ fixation in smectite layers, but with the appearance and disappearance of component modules such as M0, M1, .., Mn based on the polar 2:1 layer in I/S crystallites, as a function of temperature in hydrothermally altered rocks (illitization process occurring in the range $154-200{ }^{\circ} \mathrm{C}$ ).

The regularly interstratified mixed-layer I/S 1:1 rectorite is sometimes found in hydrothermal alteration paragenesis [13] and can be considered indicative of temperatures higher than diagenetic, characteristic of low-temperature metamorphism or hydrothermal alteration [65].

\subsubsection{Mixed-Layer Biotite/Vermiculite (B/V)}

Mixed-layer biotite/vermiculite are found in propylitic alteration facies (Table 2) of some geothermal systems (e.g., Salton Sea, USA, and Pantelleria Island, Italy [5,13]). These occur as an alteration product of either primary biotite or associated with geothermal biotite. The composition of hydrothermal mixed-layer $\mathrm{B} / \mathrm{V}$ often shows an inverse relationship between $\mathrm{K}$ and $\mathrm{Ca}$, whereas the $\mathrm{Mg} /(\mathrm{Fe}+\mathrm{Mg})$ ratio has an almost constant value with varying $\mathrm{K}$. This implies that $\mathrm{Ca}$ is the dominant interlayer cation in the vermiculite layers, whereas $\mathrm{Mg}$ only occurs in small quantities. A regular increase in interlayer $\mathrm{K}$ content of hydrothermal mixed-layer $\mathrm{B} / \mathrm{V}$ with increasing temperature was also observed [5].

\section{Clay Mineral Geothermometers}

\subsection{Chlorite Geothermometers}

The chlorite composition is the most used clay mineral-based geothermometer for estimating hydrothermal alteration temperature conditions in active and fossil hydrothermal systems. The first empirical chlorite geothermometers were based on the evidence that $\mathrm{Si}^{\mathrm{IV}}$ systematically decreases (or conversely $\mathrm{Al}^{\mathrm{IV}}$ increases) in chlorites with increasing temperature of formation $[5,20,24]$. The first empirical chlorite geothermometer was proposed by Cathelineau and Nieva [20], who found a positive correlation between $\mathrm{Al}^{\mathrm{IV}}$ and temperature in the Los Azufres geothermal system (Equation (3)).

$$
\mathrm{T}\left({ }^{\circ} \mathrm{C}\right)=106 \mathrm{Al}^{\mathrm{IV}}+18
$$

(structural formula calculated based on 28 oxygens)

Based on new chlorite analyses and fluid inclusion data on the Los Azufres geothermal system and integrating the chlorite data of McDowell and Elders [5], Cathelineau [24] proposed a modified geothermometric relationship between $\mathrm{Al}^{\mathrm{IV}}$ and temperature (Equation (4)).

$$
\mathrm{T}\left({ }^{\circ} \mathrm{C}\right)=321.98 \mathrm{Al}^{\mathrm{IV}}-61.92
$$

(structural formula calculated based on 14 oxygens). 
As an attempt to account for some aspects of bulk rock composition, some authors (Kranidiotis and MacLean [21], Equation (5), Jowett [25], Equation (6)) have suggested modifications to the geothermometric equations of Cathelineau and Nieva [20] and Cathelineau [24], to take into account the variation in $\mathrm{Fe} /(\mathrm{Fe}+\mathrm{Mg})$ in chlorite.

$$
\mathrm{T}\left({ }^{\circ} \mathrm{C}\right)=106 \mathrm{Al}^{\mathrm{IV}} \mathrm{C}+18
$$

(structural formula calculated based on 28 oxygens), where $\mathrm{Al}^{\mathrm{IV}}{ }_{\mathrm{C}}=\mathrm{Al}^{\mathrm{IV}}+0.7[\mathrm{Fe} /(\mathrm{Fe}+\mathrm{Mg})]$.

$$
\mathrm{T}\left({ }^{\circ} \mathrm{C}\right)=319 \mathrm{Al}^{\mathrm{IV}} \mathrm{C}-69
$$

(structural formula calculated based on 14 oxygens), where $\mathrm{Al}^{\mathrm{IV}}{ }_{\mathrm{C}}=\mathrm{Al}^{\mathrm{IV}}+0.1[\mathrm{Fe} /(\mathrm{Fe}+\mathrm{Mg})]$.

Several studies showed, however, that empirical chlorite geothermometers based on a direct relationship between temperature and chlorite composition, might be inappropriate. For example, the temperature-dependent variation in $\mathrm{Al}^{\mathrm{IV}}$ content, on which the chlorite geothermometer empirical calibrations are generally based, is easily applicable but does not account for the effect of the nature of the coexisting mineral assemblage and/or bulk rock composition ([26,30] and references therein). As a consequence, the empirical approach has no generality and the use of related geothermometers should not be adopted without a careful evaluation of the calibration conditions. Chlorite geothermometers, based on thermodynamic data [22,27], would circumvent this problem, because they allow accounting for the mineral assemblage and/or physicochemical parameters in addition to temperature and pressure $[22,27,75,76]$. However, the thermodynamic approach may also be questioned, considering that the large range of compositional variations in chlorites was not properly handled by thermodynamic modeling [30]. The most recent developments concerning chlorite geothermometry are the works of Inoue et al. [29] and Bourdelle et al. [30], which can be considered as semiempirical methods. These methods consider the chlorite-quartz equilibrium and use ratios of end-member activities to link chlorite composition to temperature through the equilibrium constant, $\mathrm{K}$. Although these thermometers require several assumptions to be applicable (as they do not consider explicitly the contributions of non-ideality, P, water activity, etc.), they are easy to use, they circumvent the issue of the bulk composition, and perform well in diagenetic to low-grade metamorphic contexts ([77] and references therein).

$$
\begin{gathered}
\mathrm{T}\left({ }^{\circ} \mathrm{K}\right)=1 /\left[0.00293-0.000513(\log \mathrm{K})+0.00003904(\log \mathrm{K})^{2}\right] \\
\mathrm{T}\left({ }^{\circ} \mathrm{K}\right)=9400 /(23.40-\log \mathrm{K})
\end{gathered}
$$

(Equation (7) [29], Equation (8) [30])

These geothermometers are considered particularly suited for low- $\mathrm{T}$ and low-P conditions $\left(P<400 \mathrm{MPa}\right.$ and $\left.\mathrm{T}<350{ }^{\circ} \mathrm{C}\right)$, which are typical of a hydrothermal environment [30,77]. As a consequence, their use is indicated for geothermometric calculation through chlorite composition in active and fossil hydrothermal systems, as shown by Bourdelle et al. [30] for Saint Martin (Lesser Antilles, fossil) and Toyoha (Hokkaido, active). To give a more user-friendly formulation of chlorite geothermometers of Inoue et al. [29] and Bourdelle et al. [30], Bourdelle and Cathelineau [77] developed a very useful easy-to-use graphical tool, which provides a clear visual explanation of the changes occurring in chlorite composition as a function of temperature (Figure 3). 

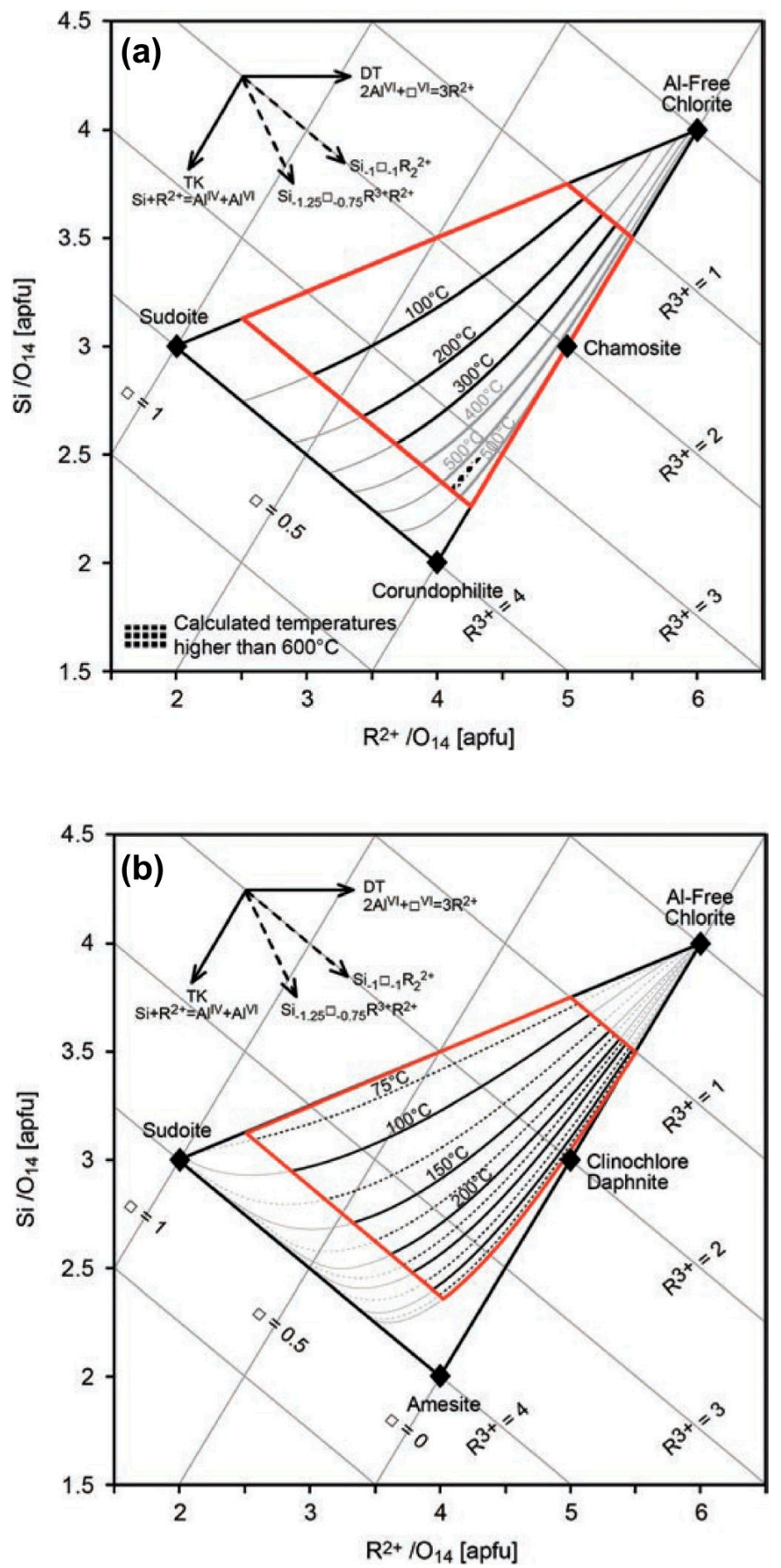

Figure 3. (a) Representation of isotherms (in $100{ }^{\circ} \mathrm{C}$ steps) calculated with the quadratic equation of Inoue et al. [29] thermometer in the $\mathrm{R}^{2+}-\mathrm{Si}$ diagram of Wiewiòra and Weiss [78]. (b) Representation of isotherms (in $25{ }^{\circ} \mathrm{C}$ steps) calculated with Bourdelle et al. [30] geothermometer in the T- $\mathrm{R}^{2+}-\mathrm{Si}$ diagram of Wiewiòra and Weiss [78]. The area of optimal reliability for the thermometer is shown in red. The two diagrams are from Bourdelle and Cathelineau [77], reproduced with permission from the European Journal of Mineralogy.

As an example, the Bourdelle et al. [30] chlorite geothermometer-based graphical tool proposed by Bourdelle and Cathelineau [77] is applied here to the composition of chlorites from the propylitic hydrothermal alteration paragenesis found in the south-eastern portion of the Larderello geothermal 
field [52]. Most of the analyzed chlorites plot between 300 and $350{ }^{\circ} \mathrm{C}$ isotherms, with some points falling slightly above the $350^{\circ} \mathrm{C}$ isotherm (Figure 4). These results are in perfect agreement with the temperatures estimated from fluid inclusion investigation and in-hole measured temperatures [52], pointing to the validity of this geothermometric approach for estimating the alteration temperature conditions in a hydrothermal environment.

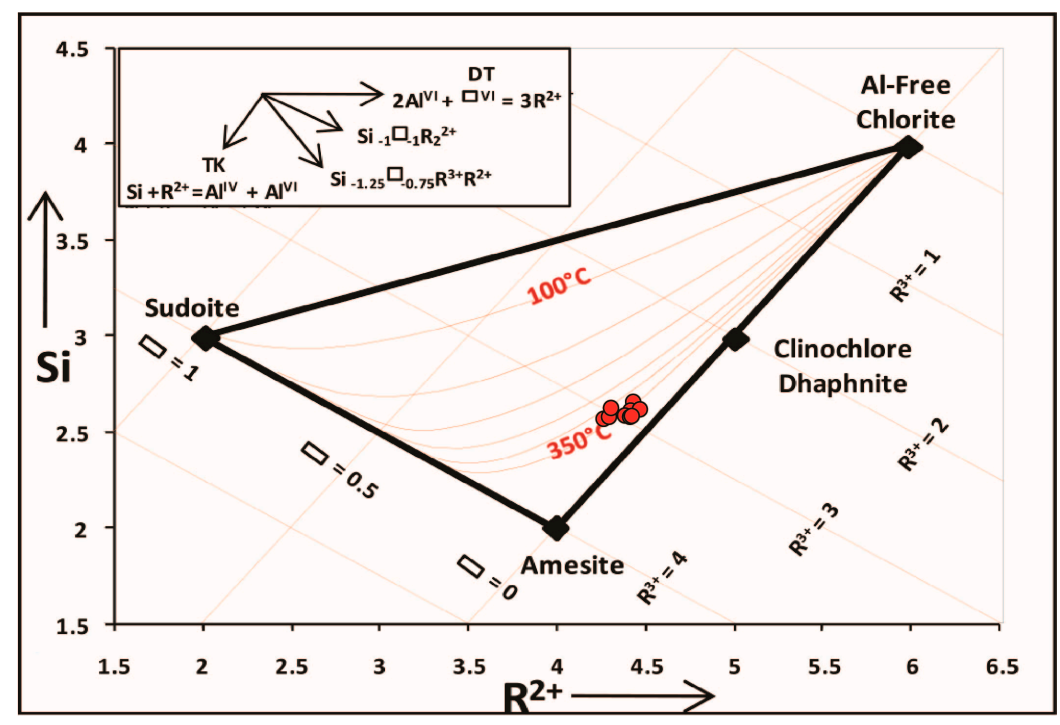

Figure 4. Chemical composition of chlorites from the Larderello geothermal field [52] plotted in the $\mathrm{T}-\mathrm{R}^{2+}-\mathrm{Si}$ diagram of Bourdelle and Cathelineau [77].

\subsection{Illite Geothermometers}

The possible relationships between illite composition variability as a function of the temperature of formation in a hydrothermal environment have been investigated since the late 1980s. In particular, Bishop and Bird [23] and Cathelineau [24] found that the values of $a_{\text {pyr }}$ and $a_{\text {musc }}$ in illite show a negative and positive dependence on temperature, respectively. However, these authors observed that each geothermal field (Salton Sea USA, Coso Hot Springs USA, Los Azufres Mexico) presented different regression lines having the same slope but different intercepts [24]. As a consequence, even if these relationships have been locally used with good results [47,52,54,55], a general relation between the variation in illite chemical composition and crystallization temperature was not developed. Battaglia [28] developed an illite geothermometer starting from the evidence that the increase in $\mathrm{K}$ content in illite was found to be the best variable, yielding a suitable positive correlation with temperature $[23,24]$, but only when applied to a single geothermal field, whereas when applied to various geothermal systems, the correlation weakened considerably. He worked on illite chemical composition from the hydrothermal alteration paragenesis of five geothermal systems (Salton Sea USA, Coso Hot Springs USA, Los Azufres Mexico, Aluto-Langano Ethiopia, Ohaaki-Broadlands New Zealand), and developed a correction algorithm (1) for the K content of the illite that yielded a good general relation with temperature.

$$
\mathrm{T}\left({ }^{\circ} \mathrm{C}\right)=267.95 \mathrm{x}+31.50, \text { where } \mathrm{x}=\mathrm{K}+|\mathrm{Fe}-\mathrm{Mg}|
$$

(Equation (9) [28])

\section{Stable Isotopes (Oxygen and Hydrogen) of Clay Minerals in Hydrothermal Systems}

The investigation of stable isotopes of alteration minerals is of relevant importance in the study of hydrothermal systems, providing useful information about their conditions of formation, the origin 
and evolution of fluids involved in hydrothermal alteration, and water/rock interaction processes (Reference [79] and references therein). In this framework, the hydrogen and oxygen isotope studies of clay minerals in hydrothermal alteration paragenesis are particularly valuable and were widely adopted in many works on active and fossil hydrothermal systems (i.e., Larderello geothermal system, Italy [52], Ischia fossil hydrothermal system, Italy [55], Lepanto porphyry and epithermal system, Philippines [80], Northparkes porphyry system, Australia [81]). These applications are functions of the $\mathrm{H}-\mathrm{O}$-isotope fractionation factors between clays and water, and temperature. As a consequence, the coupled application of clay mineral geothermometry (as well as fluid inclusion data) and stable isotope study represents a powerful tool for the reconstruction of conceptual working models of hydrothermal systems $[52,53,55,81]$. Other factors that can have a secondary effect on the stable isotope fractionation are the chemical composition of clays and of aqueous fluids, unless the salinities are very high and temperature is low [82-84]. The oxygen and hydrogen fractionation factor equations between the main clay minerals of interest for hydrothermal alteration paragenesis and water, as a function of temperature $\left({ }^{\circ} \mathrm{K}\right)$, are reported below:

Oxygen [55,85-88]:

$$
\begin{gathered}
1000 \ln \alpha_{\text {kaolinite-water }}=2.76 \times 10^{6} / \mathrm{T}^{2}-6.75 \\
1000 \ln \alpha_{\text {smectite-water }}=2.55 \times 10^{6} / \mathrm{T}^{2}-4.05 \\
1000 \ln \alpha_{\text {pyrophyllite-water }}=4.4 \times 10^{6} / \mathrm{T}^{2}-5.62 \times 10^{3} / \mathrm{T}+1.87 \\
1000 \ln \alpha_{\text {e-water }}=2.39 \times 10^{6} / \mathrm{T}^{2}-3.76 \\
1000 \ln \alpha_{\text {chlorite-water }}=2.693 \times 10^{9} / \mathrm{T}^{3}-6.342 \times 10^{6} / \mathrm{T}^{2}+2.969 \times 10^{3} / \mathrm{T} \\
1000 \ln \alpha_{C / \text { S-water }}=(2.55-0.99 I) \times 10^{6} / \mathrm{T}^{2}-(4.05+0.65 I),
\end{gathered}
$$

where $I$ is the proportion of chlorite layers in the mixed-layer C/S

$$
\begin{gathered}
1000 \ln \alpha_{\text {talc-water }}=11.7 \times 10^{6} / \mathrm{T}^{2}-25.49 \times 10^{3} / \mathrm{T}+12.48\left(\mathrm{~T}=250-450{ }^{\circ} \mathrm{C}\right) \\
1000 \ln \alpha_{\text {serpentine-water }}=11.7 \times 10^{6} / \mathrm{T}^{2}-25.49 \times 10^{3} / \mathrm{T}+12.48\left(\mathrm{~T}=250-450{ }^{\circ} \mathrm{C}\right) \\
1000 \ln \alpha_{\text {biotite-water }}=3.84 \times 10^{6} / \mathrm{T}^{2}-8.76 \times 10^{3} / \mathrm{T}+2.46
\end{gathered}
$$

Hydrogen [89-91]:

$$
\begin{gathered}
1000 \ln \alpha_{\text {kaolinite-water }}=-2.2 \times 10^{6} / \mathrm{T}^{2}-7.7 \\
1000 \ln \alpha_{\text {illite-water }}=-22.1 \times 10^{6} / \mathrm{T}^{2}+19.1\left(\mathrm{~T}=400-800{ }^{\circ} \mathrm{C}\right) \\
1000 \ln \alpha_{\text {chlorite-water }}=-30 \text { to }-40\left(\mathrm{~T}=200-500{ }^{\circ} \mathrm{C}\right) \\
1000 \ln \alpha_{\text {talc-water }}=10.88 \times 10^{6} / \mathrm{T}^{2}-41.52 \times 10^{3} / \mathrm{T}+5.61\left(\mathrm{~T}=250-450{ }^{\circ} \mathrm{C}\right) \\
1000 \ln \alpha_{\text {serpentine-water }}=3.436 \times 10^{6} / \mathrm{T}^{2}-34.736 \times 10^{3} / \mathrm{T}+21.67\left(\mathrm{~T}=250-450{ }^{\circ} \mathrm{C}\right) \\
1000 \ln \alpha_{\text {biotite-water }}=-21.3 \times 10^{6} / \mathrm{T}^{2}-2.8\left(\mathrm{~T}=400-800^{\circ} \mathrm{C}\right)
\end{gathered}
$$

(Equation (10), (11), (13) [85], Equation (12), (18) [86], Equation (14) [87], Equation (15) [55] and reference therein, Equation (16), (17), (22), (23) [88], Equation (19) [89], Equation (20), (24) [90], Equation (21) [91]).

\section{Concluding Remarks}

The study of active and fossil hydrothermal systems demonstrated that clay minerals are a fundamental tool for the identification and characterization of hydrothermal alteration facies. Their occurrence and composition are pivotal for extrapolating several important parameters, which strongly affect the development of water/rock interaction processes at the base of hydrothermal alteration (e.g., temperature, $\mathrm{pH}$ ). These parameters are a key factor for the reconstruction of conceptual 
models of active and fossil hydrothermal systems. In particular, the variation in the chemical composition of chlorite and illite revealed a strong dependence on the temperature of formation. This allowed the development of useful geothermometers that have been widely applied in the study of hydrothermal systems since the 1980s. Finally, stable isotope $(\mathrm{O}, \mathrm{H})$ investigation of clay mineral finds extensive applications for obtaining inferences on the origin and evolution of fluids involved in hydrothermal circulation.

Funding: This work is funded by projects PRA_2018_41, University of Pisa.

Acknowledgments: Many thanks are due to Francesco Cavalcante for inviting me to present this contribution to the special issue "Clays, Clay Minerals and Geology" of Minerals, and for the useful comments and suggestions on an early version of the manuscript. The manuscript benefited of the comments and suggestions of four anonymous reviewers and one Academic Editor of Minerals.

Conflicts of Interest: The author declares no conflict of interest.

\section{References}

1. Pirajno, F. Hydrothermal Mineral Deposits: Principles and Fundamental Concepts for the Exploration Geologist; Springer: Berlin/Heidelberg, Germany, 1992.

2. Browne, P.R.L. Hydrothermal alteration in active geothermal systems. Ann. Rev. Earth Planet. Sci. 1978, 6, 229-250. [CrossRef]

3. Browne, P.R.L.; Ellis, A.J. The Ohaki-Broadlands hydrothermal area, New Zeland: Mineralogy and related geochemistry. Am. J. Sci. 1970, 269, 97-131. [CrossRef]

4. Tomasson, J.; Kristmannsdottir, H. High temperature alteration minerals and thermal brines, Reykjanes, Iceland. Contrib. Mineral. Petrol. 1972, 36, 123-134. [CrossRef]

5. McDowell, S.D.; Elders, W.A. Authigenic layer silicate minerals in borehole Elmore 1, Salton Sea geothermal field, California, USA. Contrib. Mineral. Petrol. 1980, 74, 293-310. [CrossRef]

6. Reyes, A.G.; Cardile, C.M. Characterization of clay scales forming in Philippine geothermal wells. Geothermics 1989, 18, 429-446. [CrossRef]

7. Reyes, A.G. Petrology of Philippine geothermal systems and the application of alteration mineralogy to their assessment. J. Volcanol. Geotherm. Res. 1990, 43, 279-309. [CrossRef]

8. Flexser, S. Hydrothermal alteration and past and present thermal regimes in the western moat of Long Valley caldera. J. Volcanol. Geotherm. Res. 1991, 48, 303-318. [CrossRef]

9. Harvey, C.C.; Browne, P.R.L. Mixed-layer clay geothermometry in the Wairakei geothermal field, New Zealand. Clays Clay Miner. 1991, 39, 614-621. [CrossRef]

10. Schiffman, P.; Fridleifsson, G.O. The smectite-chlorite transition in drillhole NJ-15, Nesjavellir geothermal field, Iceland: XRD, BSE and electron microprobe investigations. J. Metamorph. Geol. 1991, 9, 679-696. [CrossRef]

11. Inoue, A. Formation of Clay Minerals in Hydrothermal Environments. In Origin and Mineralogy of Clays; Velde, B., Ed.; Springer: Berlin, Geramny, 1995; pp. 268-329.

12. Patrier, P.; Papapanagiotou, P.; Beaufort, D.; Traineau, M.; Bril, H.; Ross, J. Role of permeability versus temperature in the distribution of the fine $(<0.2 \mathrm{pm})$ clay fraction in the Chipilapa geothermal system (El Salvador, Central America). J. Volcanol. Geotherm. Res. 1996, 12, 101-120. [CrossRef]

13. Fulignati, P.; Malfitano, G.; Sbrana, A. The Pantelleria caldera geothermal system: Data from the hydrothermal minerals. J. Volcanol. Geotherm. Res. 1997, 75, 251-270. [CrossRef]

14. Gianelli, G.; Mekuria, N.; Battaglia, S.; Chersicla, A.; Garofalo, P.; Ruggieri, G.; Manganelli, M.; Gebregziabher, Z. Water-rock interaction and hydrothermal mineral equilibria in the Tendaho geothermal system. J. Volcanol. Geotherm. Res. 1998, 86, 253-276. [CrossRef]

15. Robinson, D.; de Zamora, A.S. The smectite to chlorite transition in the Chipilapa geothermal system, El Salvador. Am. Mineral. 1999, 84, 607-619. [CrossRef]

16. Mas, A.; Guisseau, D.; Patrier-Mas, P.; Beaufort, D.; Genter, A.; Sanjan, B.; Girard, J.P. Clay minerals related to the hydrothermal activity of the Bouillante geothermal field (Guadeloupe). J. Volcanol. Geotherm. Res. 2006, 158, 380-400. [CrossRef] 
17. Vidal, J.; Patrier, P.; Genter, A.; Beaufort, D.; Dezayes, C.; Glaas, C.; Lerouge, C.; Sanjuan, B. Clay minerals related to the circulation of geothermal fluids in boreholes at Rittershoffen (Alsace, France). J. Volcanol. Geotherm. Res. 2018, 349, 192-204. [CrossRef]

18. Shau, Y.-H.; Peacor, D.R. Phyllosilicates in hydrothermally altered basalts from DSDP Hole 504B. Leg83-a TEM and AEM study. Contrib. Mineral. Petrol. 1992, 112, 119-133. [CrossRef]

19. Martinez-Serrano, R.G.; Dubois, M. Chemical variations in chlorite at the Los Humeros geothermal system, Mexico. Clays Clay Miner. 1998, 46, 615-628. [CrossRef]

20. Cathelineau, M.; Nieva, D. A chlorite solid solution geothermometer The Los Azufres (Mexico) geothermal system. Contrib. Mineral. Petrol. 1985, 91, 235-244. [CrossRef]

21. Kranidiotis, P.; MacLean, W.H. Systematics of chlorite alteration at the Phelps Dodge massive sulfide deposit, Matagami, Quebec. Econ. Geol. 1987, 82, 1898-1911. [CrossRef]

22. Walshe, J.L. A six-component chlorite solid solution model and the conditions of chlorite formation in hydrothermal and geothermal systems. Econ. Geol. 1986, 81, 681-703. [CrossRef]

23. Bishop, B.P.; Bird, D.K. Variation in sericite compositions from fracture zones within the Coso Hot Springs geothermal system. Geochim. Cosmochim. Acta 1987, 51, 1245-1256. [CrossRef]

24. Cathelineau, M. Cation site occupancy in chlorites and illites as a function of temperature. Clay Miner. 1988, 23, 471-485. [CrossRef]

25. Jowett, E.C. Fitting iron and magnesium into the hydrothermal chlorite geothermometer. In Proceedings of the GAC/MAC/SEG Joint Annual Meeting, Toronto, ON, Canada, 27-29 May 1991. Program with Abstracts, A62, 16 .

26. de Caritat, P.; Hutcheon, I.; Walshe, J.L. Chlorite geothermometer: A review. Clays Clay Miner. 1993, 41, 219-239. [CrossRef]

27. Vidal, O.; Parra, T.; Trotet, F. A thermodynamic model for Fe-Mg aluminous chlorite using data from phase equilibrium experiments and natural pelitic assemblages in the $100^{\circ}$ to $600{ }^{\circ} \mathrm{C}, 1-25 \mathrm{~kb}$ range. Am. J. Sci. 2001, 301, 557-592. [CrossRef]

28. Battaglia, S. Variations in the chemical composition of illite from five geothermal fields: A possible geothermometer. Clay Miner. 2004, 39, 501-510. [CrossRef]

29. Inoue, A.; Meunier, A.; Patrier-Mas, P.; Rigault, C.; Beaufort, D.; Vieillard, P. Application of chemical geothermometry to low-temperature trioctahedral chlorites. Clays Clay Miner. 2009, 57, 371-382. [CrossRef]

30. Bourdelle, F.; Parra, T.; Chopin, C.; Beyssac, O. A new chlorite geothermometer for diagenetic to low-grade metamorphic conditions. Contrib. Mineral. Petrol. 2013, 165, 723-735. [CrossRef]

31. Bowers, T.S.; Jackson, K.J.; Helgeson, H.C. Equilibrium Activity Diagrams for Coexisting Minerals and Aqueous Solutions at Pressures and Temperatures to $\mathrm{kb}$ and $600^{\circ} \mathrm{C}$; Springer: Berlin/Heidelberg, Germany; New York, NY, USA, 1984; p. 305.

32. Henley, R.W.; Truesdell, A.H.; Barton, P.B., Jr. Fluid-Mineral Equilibria in Hydrothermal Systems (Reviews in Economic Geology); Society of Economic Geologists: Littleton, CO, USA, 1984; 267p.

33. Wood, S.A. Calculation of Activity-Activity and $\mathrm{Log} \mathrm{fO}_{2}-\mathrm{pH}$ Diagrams. Rev. Econ. Geol. 1998, 10, 81-96.

34. Bethke, C.M. Geochemical and Biogeochemical Reaction Modeling; Cambridge University Press: New York, NY, USA, 2007; 547p.

35. Cathelineau, M.; Oliver, R.; Garfias, A.; Nieva, O. Mineralogy and distribution of hydrothermal mineral zones in the Los Azufres (Mexico) geothermal field. Geothermics 1985, 14, 49-57. [CrossRef]

36. Elders, W.A.; Hoagland, J.R.; Williams, A.E. Distribution of hydrothermal mineral zones in the Cerro Prieto geothermal field of Baja California, Mexico. Geothermics 1981, 10, 245-253. [CrossRef]

37. Papapanagiotou, P.; Patrier, P.; Beaufort, D.; Fouillac, A.-D.; Rojas, J. Occurence of smectites and smectite-rich mixed layers at high temperature within reservoirs of active geothermal fields. In Proceedings of the World Geothermal Congress, Florence, Italy, 18-31 May 1995; pp. 1071-1076.

38. Ruggieri, G.; Petrone, C.M.; Gianelli, G.; Arias, A.; Henriquez, H.T. Hydrothermal alteration in the Berlin geothermal field (El Salvador): New data and discussion on the natural state of the system. Per. Mineral. 2006, 75, 293-312.

39. Deer, W.A.; Howie, R.A.; Zussman, J. An Introduction to the Rock-Forming Minerals; Longmans: London, UK, 1966; p. 270.

40. Stoffregen, R.E.; Alpers, C.N. Woodhouseite and svanbergite in hydrothermal ore deposits: Products of apatite destruction during advanced argillic alteration. Can. Mineral. 1987, 25, 201-211. 
41. Dill, H.G. A geological and mineralogical review of clay mineral deposits and phyllosilicate ore guides in Central Europe-A function of geodynamics and climate change. Ore Geol. Rev. 2020, 119, 103304. [CrossRef]

42. Dill, H.G.; Fricke, A.; Henning, K.-H.; Theune, C.H. An aluminium-phosphate mineralization from the hypogene La Vanguardia kaolin deposit (Chile). Clay Miner. 1995, 30, 249-256. [CrossRef]

43. Dill, H.G.; Bosse, H.-R.; Henning, K.-H.; Fricke, A.; Ahrend, H. Mineralogical and chemical variations in hypogene and supergene kaolin deposits in a mobile fold belt-The Central Andes of northwestern Peru. Mineral. Depos. 1997, 32, 149-163. [CrossRef]

44. Dill, H.G.; Bosse, H.-R.; Kassbohm, J. Mineralogical and chemical studies of volcanic-related argillaceous industrial minerals of the Central American Cordillera (western El Salvador). Econ. Geol. 2000, 95, 517-538. [CrossRef]

45. Dill, H.G. A comparative study of APS minerals of the Pacific Rim fold belts with special reference to South American argillaceous deposits. J. S. Am. Earth Sci. 2003, 16, 301-320. [CrossRef]

46. Zhang, S.-Y.; Zhang, H.-F. Genesis of the Baiyun pyrophyllite deposit in the central Taihang Mountain, China: Implications for gold mineralization in wall rocks. Ore Geol. Rev. 2020, 120, 103313. [CrossRef]

47. Reyes, A.G.; Giggenbach, W.F.; Saleras, J.R.M.; Salonga, N.D.; Vergara, M.C. Petrology and geochemistry of Alto Peak, a vapor-cored hydrothermal system, Leyte Province, Philippines. Geothermics 1993, 22, 479-519. [CrossRef]

48. Arribas, A., Jr. Characteristics of high-sulfidation epithermal deposits, and their relation to magmatic fluid. Mineral. Assoc. Canada Short Course 1995, 23, 419-454.

49. Guggenheim, S.; Adams, J.M.; Bain, D.C.; Bergaya, F.; Brigatti, M.F.; Drits, V.A.; Formoso, M.L.L.; Galan, E.; Kogure, T.; Stanjek, H. Summary of recommendations of nomenclature committees relevant to clay mineralogy: Report of the Association Internationale pour l'Etude des Argiles (AIPEA) Nomenclature Committee for 2006. Clay Miner. 2006, 41, 863-877. [CrossRef]

50. Zang, W.; Fyfe, W.S. Chloritization of the hydrothermally altered bedrock at the Igarapé Bahia gold deposit, Carajás, Brazil. Mineral. Depos. 1995, 30,30-38. [CrossRef]

51. Teklemariam, M.; Battaglia, S.; Gianelli, G.; Ruggieri, G. Hydrothermal alteration in the Aluto-Langano geothermal field, Ethiopia. Geothermics 1996, 25, 679-702. [CrossRef]

52. Boyce, A.J.; Fulignati, P.; Sbrana, A. Deep hydrothermal circulation in a granite intrusion beneath Larderello geothermal area (Italy): Constraints from mineralogy, fluid inclusions and stable isotopes. J. Volcanol. Geotherm. Res. 2003, 126, 243-262. [CrossRef]

53. Klein, E.L.; Harris, K.; Giret, A.; Moura, C.A.V. The Cipoeiro gold deposit, Gurupi Belt, Brazil: Geology, chlorite geochemistry, and stable isotope study. J. S. Am. Earth Sci. 2007, 23, 242-255. [CrossRef]

54. Murakami, H. Variations in Chemical Composition of Clay Minerals and Magnetic Susceptibility of Hydrothermally Altered Rocks in the Hishikari Epithermal Gold Deposit, SW Kyushu, Japan. Resour. Geol. 2008, 58, 1-24. [CrossRef]

55. Sbrana, A.; Fulignati, P.; Marianelli, P.; Boyce, A.J.; Cecchetti, A. Exhumation of an active magmatic-hydrothermal system in a resurgent caldera environment: The example of Ischia (Italy). J. Geol. Soc. Lond. 2009, 166, 1061-1073. [CrossRef]

56. Inoue, A.; Kurokawa, K.; Hatta, T. Application of chlorite geothermometry to hydrothermal alteration in Toyoha geothermal system, Southwestern Hokkaido, Japan. Resour. Geol. 2010, 60, 52-70. [CrossRef]

57. Pant, S.; Singh, S.; Sahoo, P.R.; Kumar, A.; Saravanan, B.; Venkatesh, A.S.; Yadav, G.S.; Kumar, P. Mineral chemistry and geothermometry of chlorites in relation to physicochemical conditions of uranium mineralization in the central part of the Singhbhum Shear Zone, eastern India. Ore Geol. Rev. 2019, 112, 102997. [CrossRef]

58. Chu, G.; Zhang, S.; Zhang, X.; Xiao, B.; Han, J.; Zhang, Y.; Cheng, J.; Feng, Y. Chlorite chemistry of Tongshankou porphyry-related $\mathrm{Cu}-\mathrm{Mo}-\mathrm{W}$ skarn deposit, Eastern China: Implications for hydrothermal fluid evolution and exploration vectoring to concealed orebodies. Ore Geol. Rev. 2020, 122, 103531. [CrossRef]

59. Pacey, A.; Wilkinson, J.J.; Cooke, D.R. Chlorite and Epidote Mineral Chemistry in Porphyry Ore Systems: A Case Study of the Northparkes District, NSW, Australia. Econ. Geol. 2020, 115, 701-727. [CrossRef]

60. Jacobs, D.C.; Parry, W.T. A comparison of the geochemistry of biotite from some Basin and Range stocks. Econ. Geol. 1976, 71, 1029-1035. [CrossRef]

61. Fulignati, P.; Gioncada, A.; Sbrana, A. Hydrothermal alteration in the subsoil of Porto di Levante, Vulcano (Aeolian Islands, Italy). Acta Vulcanol. 1996, 8, 29-138. 
62. Manuella, F.C. Vein mineral assemblage in partially serpentinized peridotite xenoliths from Hyblean Plateau (south-eastern Sicily, Italy). Per. Mineral. 2011, 80, 247-266.

63. Malvoisin, B.; Brunet, F.; Carlut, J.; Roumejon, S.; Cannat, M. Serpentinization of oceanic peridotites: 2. Kinetics and processes of San Carlos olivine hydrothermal alteration. J. Geophys. Res. 2012, 117, B04102. [CrossRef]

64. Pozo, M.; Calvo, J.P. An Overview of Authigenic Magnesian Clays. Minerals 2018, 8, 520. [CrossRef]

65. Srodon, J. Nature of mixed-layer clays and mechanisms of their formation and alteration. Ann. Rev. Earth Planet. Sci. 1999, 27, 19-53. [CrossRef]

66. Inoue, A.; Utada, M. Smectite-to-chlorite transformation in thermally metamorphosed volcanoclastic rocks in the Kamikita area, northern Honshu, Japan. Am. Mineral. 1991, 76, 628-640.

67. Schiffman, P.; Staudigel, H. The smectite to chlorite transition in a fossil seamount hydrothermal system: The Basement Complex of La Palma, Canary Islands. J. Metamorph. Geol. 1995, 13, 487-498. [CrossRef]

68. Meunier, A.; Inoue, A.; Beaufort, D. Chemiographic analysis of trioctahedral smectite-to-chlorite conversion series from the Ohyu caldera, Japan. Clays Clay Miner. 1991, 39, 409-415. [CrossRef]

69. Buatier, M.D.; Fruh-Green, G.L.; Karpoff, A.M. Mechanisms of Mg-phyllosilicate formation in a hydrothermal system at a sedimented ridge (Middle Valley, Juan de Fuca). Contrib. Mineral. Petrol. 1995, 122, 134-151. [CrossRef]

70. Bettison-Varga, L.A.; MacKinnon, D.R.; Schiffman, P. Integrated TEM, XRD and electron microprobe investigation of mixed- layer chlorite-smectite from the Point Sal ophiolite, California. J. Metamorph. Geol. 1991, 9, 697-710. [CrossRef]

71. Robinson, D.; Bevins, R.E.; Rowbotham, G. The characterization of mafic phyllosilicates in low-grade metabasalts from eastern North Greenland. Am. Mineral. 1993, 78, 377-390.

72. Inoue, A.; Meunier, A.; Beaufort, D. Illite-smectite mixed-layer minerals in felsic voclaniclastic rocks from drill cores, Kakkonda, Japan. Clays Clay Miner. 2004, 52, 66-84. [CrossRef]

73. Inoue, A.; Lanson, B.; Marques-Fernandes, M.; Sakharov, B.A.; Murakami, T.; Meunier, A.; Beaufort, D. Illite-smectite mixed-layer minerals in the hydrothermal alteration of volcanic rocks: I. one-dimensional XRD structure analysis and characterization of component layers. Clays Clay Miner. 2005, 53, 423-439. [CrossRef]

74. Murakami, T.; Inoue, A.; Lanson, B.; Meunier, A.; Beaufort, D. Illite-smectite mixed-layer minerals in hydrothermal alteration of volcanic rocks: II. One-dimensional HRTEM structure-images and formation mechanism. Clays Clay Miner. 2005, 53, 440-451. [CrossRef]

75. Vidal, O.; Parra, T.; Vieillard, P. Thermodynamic properties of the Tschermak solid solution in Fe-chlorite: Application to natural examples and possible role of oxidation. Am. Mineral. 2005, 90, 347-358. [CrossRef]

76. Vidal, O.; De Andrade, V.; Lewin, E.; Munoz, M.; Parra, T.; Pascarelli, S. P-T-deformation- $-\mathrm{Fe}^{3+} / \mathrm{Fe}^{2+}$ mapping at the thin section scale and comparison with XANES mapping: Application to a garnet-bearing metapelite from the Sambagawa metamorphic belt (Japan). J. Metamorph. Geol. 2006, 24, 669-683. [CrossRef]

77. Bourdelle, F.; Cathelineau, M. Low-temperature chlorite geothermometry: A graphical representation based on a T-R ${ }^{2+}-$ Si diagram. Eur. J. Mineral. 2015, 27, 617-626. [CrossRef]

78. Wiewiora, A.; Weiss, Z. Crystallochemical classifications of phyllosilicates based on the unified system of projection of chemical composition: II The chlorite group. Clay Miner. 1990, 25, 83-92. [CrossRef]

79. Campbell, A.R.; Larson, P.B. Introduction to stable isotope applications in hydrothermal systems. Rev. Econ. Geol. 1998, 10, 173-193.

80. Hedenquist, J.W.; Arribas Jr, A.; Reynolds, T.J. Evolution of an intrusion-centered hydrothermal system: Far Southeast-Lepanto porphyry and epithermal Cu-Au deposits, Philippines. Econ. Geol. 1998, 93, 373-404. [CrossRef]

81. Pacey, A.; Wilkinson, J.J.; Boyce, A.J.; Millar, I.L. Magmatic fluids implicated in the formation of propylitic alteration: Oxygen, hydrogen, and strontium isotope constraints from the Northparkes porphyry $\mathrm{Cu}-\mathrm{Au}$ District, New South Wales, Australia. Econ. Geol. 2020, 115, 729-748. [CrossRef]

82. Truesdell, A.H. Oxygen isotope activities and concentrations in aqueous salt solutions at elevated temperatures: Consequences for isotope geochemistry. Earth Planet. Sci. Lett. 1974, 23, 387-396. [CrossRef]

83. Graham, C.M.; Sheppard, S.M.F. Experimental hydrogen isotope studies, II. Fractionations in the systems epidote- $\mathrm{NaCl}-\mathrm{H}_{2} \mathrm{O}$, epidote- $\mathrm{CaCl}_{2}-\mathrm{H}_{2} \mathrm{O}$ and epidote-seawater, and the hydrogen isotope composition of natural epidotes. Earth Planet. Sci. Lett. 1980, 49, 237-251. [CrossRef] 
84. Horita, J.; Cole, D.R.; Wesolowski, D.J. The activity-composition relationship of oxygen and hydrogen isotopes in aqueous salt solutions: II. Vapor-liquid water equilibration of mixed salt solutions from 50 to 100 and geochemical implications. Geochim. Cosmochim. Acta 1993, 57, 4703-4711. [CrossRef]

85. Sheppard, S.M.F.; Gilg, H.A. Stable isotope geochemistry of clay minerals. Clay Miner. 1996, 31, 1-24. [CrossRef]

86. Zheng, Y.-F. Calculation of oxygen isotope fractionation in hydroxyl-bearing silicates. Earth Planet. Sci. Lett. 1993, 120, 247-263. [CrossRef]

87. Cole, D.R.; Ripley, E.M. Oxygen isotope fractionation between chlorite and water from 170 to $350{ }^{\circ} \mathrm{C}$ : A preliminary assessment based on partial exchange and fluid/rock experiments. Geochim. Cosmochim. Acta 1998, 63, 449-457. [CrossRef]

88. Saccocia, P.J.; Seewald, J.S.; Shanks, W.C., III. Oxygen and hydrogen isotope fractionation in serpentine-water and talc-water systems from 250 to $450{ }^{\circ} \mathrm{C}, 50 \mathrm{MPa}$. Geochim. Cosmochim. Acta 2009, 76, 6789-6804. [CrossRef]

89. Gilg, H.A.; Sheppard, S.M.F. Hydrogen isotope fractionation between kaolinite and water revisited. Geochim. Cosmochim. Acta 1996, 60, 529-533. [CrossRef]

90. Suzuoki, T.; Epstein, S. Hydrogen isotope fractionation between OH-bearing minerals and water. Geochim. Cosmochim. Acta 1976, 40, 1229-1240. [CrossRef]

91. Graham, C.M.; Viglino, J.A.; Harmon, R.S. Experimental study of hydrogen-isotope exchange between aluminous chlorite and water and of hydrogen diffusion in chlorite. Am. Mineral. 1987, 72, 566-579.

Publisher's Note: MDPI stays neutral with regard to jurisdictional claims in published maps and institutional affiliations.

(C) 2020 by the author. Licensee MDPI, Basel, Switzerland. This article is an open access article distributed under the terms and conditions of the Creative Commons Attribution (CC BY) license (http://creativecommons.org/licenses/by/4.0/). 